\title{
STRATEGIC INVESTMENT AND EXCESS CAPACITY: THE CASE OF MALAYSIAN PALM BIODIESEL INDUSTRY
}

\author{
CHOO SZE YI \\ ALIAS RADAM \\ Faculty of Economics and Management \\ Universiti Putra Malaysia \\ MAD NASIR SHAMSUDIN \\ Faculty of Agriculture \\ Universiti Putra Malaysia
}

\begin{abstract}
With the growing demand of palm biodiesel worldwide, the government has recently announced the implementation of palm biodiesel programme effective July 2014. The implementation will boost the palm biodiesel industry and heighten the demand for palm biodiesel in the domestic market as well as in the international market. This paper thus examines the relationship between the use of strategic investment in excess capacity and the industry entry condition, using logit model. This study covered study period from year 2006 to 2013. The results from this study will further help policymakers to develop policy that is parallel with the condition of the industry.
\end{abstract}

Keywords: Palm biodiesel industry, strategic investment, excess capacity, market entry.

\section{Introduction}

Malaysia is known as the world's largest palm oil exporter and producer. In 2011, the production of palm oil amounted to a total of 18.9 million tonnes of palm oil from 5.0 million hectares of land. It plays a crucial role in fulfilling the growing needs for oil globally. The capacity of 10 operational palm biodiesel plants in 2012 was estimated at 1.5 million tonnes (MPOB, 2013). As the demand for biodiesel grows worldwide, Malaysia ought to ensure that its production is capable to meet the high standards of innovation and expertise demanded by world markets and continue to sustain its quality of palm oil production to further establish its success in the industry.

The demand for Malaysian palm biodiesel has been growing steadily since 2006. The highest export volume was recorded in 2009 with exports worth RM 605.8 million and a volume of 227.5 thousand tonnes. However, in recent years, palm biodiesel exports dropped drastically to 50 thousand tonnes, which is equivalent to RM 179.7 million worth in 2011, based on statistics provided by MPIC (2011). In order to maintain the competitive edge and its global status in palm oil biodiesel industry, major producers, domestic industry players, and relevant government agencies should work closely together to sustain its position globally and to stay competitive in the industry in the future.

The main purpose of this study was to address the following questions. Firstly, how strategic investment in excess capacity influences market entry in Malaysian palm biodiesel industry? Secondly, is excess capacity an effective deterrence tool? This study aimed to analyse investment in capacity affected market entry 
using the logit model. This study hoped to establish and contribute new insight that can be added to the academic literature. This insight is crucial in understanding how Malaysian palm biodiesel industry can survive and maintain its status as one of the largest and prominent producers in the global market.

\section{Theory and Prior Empirical Evidence}

Generally, investment in excess capacity is believed to help a business or an industry to expand its production to attain lower cost than its rival in times of peak demand or in the occasion of new entry. It is conveyed as a threat to rivals and new entrants, in that the incumbent earlier retains some of its capacity and expands its production to full scale when entry occurs to lower the incumbent's cost and increase incumbent's revenue. Excess capacity enables the incumbent to cater to upsurge in demand and in some cases leads to liberalisation of trade where incumbent ventures and participates in the global market.

On the other hand, investment in excess capacity is viewed as an inefficient act in terms of productivity. This is due to the perspective that by retaining certain level of capacity, the intended production falls short of the actual production level, in which the firm does not produce at the level that it is capable of. Capacity that is not utilised is considered wasteful, as efficient allocation of capacity would have been of useful consumption and benefit to consumers. The level of production that is not attainable and unused reflects incompetent or inadequate economy. Some economists questioned the practicability of this theory adding that the cost of excess capacity is too large to be endured mainly by small businesses or organisations.

More often than not, strategic investment in excess capacity contributes to globalisation of that particular sector. The term globalisation involves rapid increase of economic activities in terms of productivity and marketing of products across the world. Investment that is done strategically for that purpose would cause a spike in supply, where it is not only enough to supply to the domestic market, but it also enables the firm to extend its access to the market internationally. A firm that is interested in venturing into the global market commonly holds excess capacity in its production with the intention to expand production to accommodate the massive demand in the market effectively.

The significance and effectiveness of excess capacity is to be determined. This study focused on the role played by strategic capacity in palm biodiesel industry in Malaysia. No studies have been conducted in the area of strategic investment and capacity in the Malaysian palm biodiesel industry. This study had hoped to achieve a new insight into the use of strategic investment and capacity, particularly in the palm biodiesel industry in Malaysia. Due to the importance of this industry to Malaysia, it is crucial for research to be done in this industry to preserve the country's position as the leading producer in the world market.

\section{i. Strategic Behaviour and Strategic Investment}

Strategic behaviour has always been an important issue studied in industrial economics over the years. It signifies the crucial survival methods for firms to remain competitive and effective in the industry despite various challenges from established rivals and new comers into the market. The explanation of strategic behaviour ${ }^{1}$ is indebted to the work of both Schelling (1960) and Harrington (1987). The definition by Schelling (1960) touched on the possibility of a behaviour of a firm to indirectly change the action taken by another firm. While the work by Harrington (1987) suggested other firms' behaviour is led directly by a firm's strategy. By combining the work of these two scholars, the definition of strategic behaviour is amplified to impact firms in both direct and indirect ways. One way or another, it is meant to raise rivals' cost and to minimise rivals' revenue (Church \& Ware, 2000). It is then defined by Gilbert (1989) as an act by established firms to shield their position in the market. Generally speaking, strategic behaviour involves established firms' 
reactions, whether collectively or individually, to influence the conduct of other competitors for their own benefit.

Strategic behaviour involves investment behaviour in diverse aspects from product differentiation and capacity allocation, to advertising and research and development. As Gilbert (1989) stated, it is in the concern of strategic entry deterrence that one's behaviour or action in a game is to impact or affect the behaviour of another ${ }^{2}$. It functions as a device to hinder mobility in resources. It can also be put in as a way to bond investment of resources with the firm that limits the ability of firms to move freely once investment is made. The term used by Dixit (1980) in his model of investment in strategic entry deterrence is similar to that of Gilbert's in that both new and established firms are bounded by sunk cost. It is an expense that is irrecoverable. On top of these opinions by two renowned scholars, one can conclude that new firms and established firms may play safe and hesitate to invest in this indistinct situation, where it is not known how it would turn out to be.

Through the work of Wood (2005), investment can be categorised into positive and negative influences. Positive investments is mainly investment to maintain market share, while negative investment is to preempt or deter entry. Strategic investment comprises both positive and negative investment for one to remain in the marketplace by making established rival's expansion and the entry of new entrant unsuccessful and unprofitable (Church \& Ware, 2000).

\section{ii. Excess Capacity}

Excess capacity is a condition in which a firm produces at a lower rate of its potential scale . $^{3}$ It can also be defined as the difference between the real output and its potential output. In other words, the amount produced is less than what it is able to generate. Demand of a particular product is more than its supply, causing shortage of goods in the market. Bain (1962) described that this condition is often seen during the peak period of demand in the market. The firm engages in investment in excess capacity by preserving a huge amount of capacity unexploited for the purpose of future usage. This stands up when Driver (2000) claimed that demand shocks may be the primary reason that causes investment in excess capacity to take place. More often than not, the firm carries excess capacity in times of uncertainty or fluctuations of demand of particular goods.

This view is in line ${ }^{4}$ with Schelling's (1960) idea that one should make a threat convincing to one's opponent by committing into cost that is so huge in which it works as a signal to the opponent that one is committed to restrain entry into the market or that one is ready for major expansion of capacity (Kirman and Masson, 1986). These studies confirmed that investment in capacity does appear to delay the progress of entry of new comers into the industry, while in some cases it does deter advancement into the market.

Dixit (1979), Allen (1993), and Mason and Polasky (1994) extended to comment that investment in excess capacity strategically acts as an entry barrier. They believed potential entrants would have expected competition from established firms in the event of their entry, but it is in their least expectation that established firms would join forces cooperatively to compete against them. Dixit (1979) further added that a workable strategy ${ }^{5}$ is to make a credible threat to maintain enough capacity upon entry and the ability to effectively deter entry of another firm into the market entirely. This would then stop the advancement or future entry (Wilson, 1992) of potential entrants into the market.

Through their understanding in strategic entry deterrence Comanor and Frech (1984) expressed that a rival is intimidated by the incumbent when the latter invests in additional capacity. In the short-run, the profitability of investment in excess capacity may be negative, but they argued that focusing on the long-run, it would be a worthwhile investment as the incumbent would profit from that. Similarly, Tay (2005) said strategic investment in excess capacity has 
led firms to reduce the output level of incumbent rivals using the huge amount of capacity built in the past. Evidence also signified excess capacity installed by the dominant firm as an intimidation to limit behaviour of rivals, not to preempt entry of entrant into the market.

Empirical results obtained by Driver (2000) indicated that excess capacity for precautionary purpose in times of uncertainty of demand is practised more frequently than for the strategic purpose to deter entry. It was asserted that uncertainty in general is divided into two types. That is, firstly, uncertainty of demand and secondly, uncertainty of strategy adopted by rival or competitor in the market. Both types of uncertainties have caused firms to continually invest in excess capacity to remain competitive in the market as proposed by Besanko, Doraszelski, Lu, and Satterthwaite (2010).

Excess capacity in the opinion of Le Coq and Sturluson (2006) allows incumbents to generate extra profits from inexperienced ${ }^{6}$ entrants. Excess capacity in the market is often high and price is low prior to entry of a new firm. This is associated with the nature of inexperienced firms in which they tend to behave aggressively facing incumbents upon entry. When an inexperienced entrant reacts, it is driven by the instinct to selfdefend in a hostile way to protect its newly-built establishment.

\section{Methodology}

The strategic investment in excess capacity of an industry, or specifically a firm, was estimated in this study using a logit model proposed by Lieberman (1987). Investment of firm in capacity is a dichotomous one, with the probability whether to invest in strategic excess capacity or not in a given year.

It is assumed, unit cost function is $r k+c x$, where $r k$ is fixed investment cost per period and $c$ is marginal cost per unit $x$ produced. Fixed cost of individual plant per period equals to $r k / N$ Industry price, $P=r k+c+v$, is maintained at some arbitrary level, $v$, above unit cost. It is also assumed that $g$ is the growth rate of demand and before additional new capacity is added in the production; all idle capacity is utilised and used before hand.

Based on the conditions above, a new plant bears an instantaneous profit, $\pi$, exceeds zero, in time of its plant building. If $U_{0}$ at time $t_{0}$ is the industry capacity utilisation, output equal the residual demand at the time $t$ of the opening of the plant is

$g\left(t-t_{0}\right)-\left(1-U_{0}\right)$

in which, $(r k+v)$ is the margin earned. An additional plant that is built at the first point $t$ ' is: $\pi=\left[g\left(t^{\prime}-t_{0}\right)-\left(1-U_{0}\right)\right](r k+v)-r k / N>0$

The decision whether or not to build the plant is assumed to be made earlier, at time $t^{\prime}-t_{c}$, in which $t_{c}$ is the construction lead time. One should note that, the positive function of decision statistic that can be observed empirically is $g$ and $U_{0}$, while a negative function is $1 / N$.

A logit model can be used to estimate the decision structure represented in (1). For each observation year $t$, observation of whether a new plant is completed can be made. The decision to invest is assumed to be made previously, in year $t-t$, according to the rates of industry growth and capacity utilisation in the time range of the observation. Meanwhile, $g_{t}-t_{c}$ is the forecasted market growth based on recent historical rate.

The logit model that will be used to estimate the strategic investment in excess capacity is given as:

$y_{t}^{\prime}=-b_{1}+b_{1} t g_{t-t c}+b_{1} U_{t-t c}-b_{2} 1 / N_{t}+e_{t}$

where,

$y^{\prime} \quad$ : Probability of capacity expansion (Investment in capacity)

$t_{c} \quad$ : Observation of current year

$g_{t-t c}:$ Market growth based on historical rate

$U_{t-t c}$ : Capacity expansion based on historical rate

$1 / N_{t}:$ Additional plant of capacity

$e_{t} \quad:$ Random error term 
The coefficients in (2) are determined only up to a random multiplicative constant where, $b_{1}$ is proportional to $(r k+v)$, and $b_{2}$ is proportional to rk (Lieberman, 1987).

It is worth noting that the above logit model is only predicting the establishment of new plants in the industry, be it by the incumbents or rather by the entrants is not being further distinguished. The time-period for this study was proposed from year 2006 to year 2013 involving 12 palm biodiesel plants actively in operation in Malaysia. The data related to this study will be collected from Malaysian Palm Oil Board (MPOB) and Department of Statistics, Malaysia.

\section{Conclusion}

This study intends to analyse the use of strategic investment and capacity in Malaysian palm biodiesel industry. This study hopes to evaluate the relationships strategic investment and capacity has on market entry using the proposed logit model. It is hoped that this study will bring new insights into the effect of strategic investment and excess capacity on market entry in palm biodiesel industry. Since the palm biodiesel industry is becoming a highly potential and highly demanded industry in the future, it is essential for Malaysia to continue to place extra effort in developing this industry. Through this study, it is also hoped that the Malaysian government will be able to form and implement a thorough policy and plan to further expand and preserve Malaysia's position in the global market.

\section{End Notes}

1 It is defined as a situation in which firms are mindful of one another's behaviour and one's behaviour or decision can impact others in the same industry. These firms are inter-related with each other (As defined by BusinessDictionary.com; http://www.businessdictionary.com/definition/ strategic-behavior.html).

2 Gilbert's explanation is parallel with Schelling's (1960) definition on strategic behaviour in that he claimed that a rival is often lured or manipulated to make decision that benefits the manipulator. It is also in the nature of strategic behaviour to convey an act or threat to become a practical commitment.

3 Based on definition and understanding adapted from Investopedia (Source: Investopedia http:// www.investopedia.com/terms/e/excesscapacity. asp).

4 Chapter 2: An Essay on Bargaining (pp. 22) in "The Strategy of Conflict" (1960), a book written by Thomas C. Schelling.

5 Benoît and Krishna (1987) also concluded that the primary intention behind employing the strategy of excess capacity is for it to work as a threat to rivals or entrants.

6 Referred to as newly established entrant in the market with no prior history in the industry.

\section{References}

Allen, B. (1993). Capacity precommitment as an entry barrier for price-setting firms. International Journal of Industrial Organisation, 11(1), 63-72.

Bain, J. S. (1962). Barriers to new competition. Cambridge, Massachusetts: Harvard University Press.

Benoît, J.-P., \& Krishna, V. (1987). Dynamic duopoly: Prices and quantities. The Review of Economic Studies, 54(1), 2335.

Besanko, D., Doraszelski, U., Lu, L. X., \& Satterthwaite, M. (2010). On the role of demand and strategic uncertainty in capacity investment and disinvestment dynamics. International Journal of Organisation, 28(4), 383-389.

Church, J., \& Ware, R. (2000). Industrial organisation: A strategic approach. Boston: Irwin McGraw-Hill.

Comanor, W. S., \& Frech, H. E. (1984). Strategic behaviour and anitrust analysis. The American Economic Review, 74(2), 372-376.

Dixit, A. (1979). A model of duopoly suggesting a theory of entry barriers. The Bell Journal of Economics, 10(1), 20-32.

Dixit, A. (1980). The role of investment in entrydeterrence. The Economic Journal, 90(357), 95-106. 
Driver, C. (2000). Capacity utilisation and excess capacity: Theory, evidence and policy. Review of Industrial Organisation, 16(1), 69-87.

Gilbert, R. J. (1989). Mobility barriers and the value of incumbency. In R. Schmalensee \& R. D. Willig (Eds.), Handbook of industrial organisation, volume I (pp. 476-535). Amsterdam, Netherlands: Elsevier Science B.V.

Harrington, J., Jr. (1987). Strategic behaviour and market structure. In J. Eatwell, M. Milgate, \& P. Newman (Eds.), The New Palgrave: A dictionary of economics (pp. 513-515). London: MacMillan Press.

Kirman, W. I., \& Masson, R. T. (1986). Capacity signals and entry deterrence. International Journal of Industrial Organisation, 4(1), 25-42.

Le Coq, C., \& Sturluson, J. T. (2006, June). Can bounded rationality explain excess capacity? Paper presented at Economic Science Association World Meeting 2007, Parallel Sessions 3 Stream 6, LUISS Rome, Italy.

Lieberman, M. B. (1987). Excess capacity as a barrier to entry: An empirical approach. The Journal of Industrial Economics, 35(4), 607-627.
Malaysian Palm Oil Board. (MPOB). (2013). Malaysian oil palm statistics (Various issues). Kuala Lumpur: Ministry of Primary Industries. Mason, C. F., \& Polasky, S. (1994). Entry deterrence in the commons. International Economic Review, 35(2), 507-525.

MPIC. (2011). Statistics on Commodities 2011. Putrajaya: Ministry of Plantation and Industries and Commodities (MPIC).

Schelling, T. C. (1960). The strategy of conflict. Cambridge, Massachusetts: Harvard University Press.

Tay, C. M. (2005). Strategic investment and excess capacity: A study of the Taiwanese flour industry. Journal of Applied Economics, 8(1), 153-170.

Wilson, R. (1992). Strategic model of entry deterrence. In R. J. Aumann, \& S. Hart (Eds.), The handbook of game theory with economic application, volume 1 (pp. 305-329). Amsterdam: Elsevier Science B.V.

Wood, A. (2005). Investment interdependence and the coordination of lumpy investments: Evidence from the British brick industry. Applied Economics, 37(1), 37-49. 